\title{
Article
}

\section{Optimizing volumetric sweep efficiency in water flooding by streamline simulation}

Sajjadi, Seyed Adib, Nasriani, Hamid Reza, Dailami, Keyvan and Alizadeh, Naser

Available at http://clok.uclan.ac.uk/17199/

Sajjadi, Seyed Adib, Nasriani, Hamid Reza ORCID: 0000-0001-9556-7218, Dailami, Keyvan and Alizadeh, Naser (2017) Optimizing volumetric sweep efficiency in water flooding by streamline simulation. Energy Sources, Part A: Recovery, Utilization, and Environmental Effects . pp. 1-8. ISSN 1556-7036

It is advisable to refer to the publisher's version if you intend to cite from the work. http://dx.doi.org/10.1080/15567036.2011.596903

For more information about UCLan's research in this area go to http://www.uclan.ac.uk/researchgroups/ and search for <name of research Group>.

For information about Research generally at UCLan please go to http://www.uclan.ac.uk/research/

All outputs in CLoK are protected by Intellectual Property Rights law, including Copyright law. Copyright, IPR and Moral Rights for the works on this site are retained by the individual authors and/or other copyright owners. Terms and conditions for use of this material are defined in the policies page. 


\title{
Optimising Volumetric Sweep Efficiency in Water Flooding by Streamline Simulation
}

\author{
Seyed Adib Sajjadi' ${ }^{1}$, Hamid Reza Nasriani' ${ }^{2}$, Keyvan Dailami ${ }^{1}$, Naser Alizadeh ${ }^{3}$ \\ ${ }^{1}$ Islamic Azad University, Omidieh Branch, Omidieh, Iran. \\ Adib.sajjadi@gmail.com,7185981661 \\ ${ }^{2}$ School of Engineering, Faculty of Science and Technology, University of Central Lancashire, \\ Preston, United Kingdom \\ ${ }^{3}$ Amirkabir University of Technology (Tehran Polytechnic), Tehran, Iran
}

\section{Abstract}

Early shutting time in production wells due to water production, performs an important role to determine production efficiency and useful life of the reservoir.

In this study, in order to postpone the shut in time of producing wells, increase oil displacement and enhance production efficiency, production and injection wells capabilities with respect to their position in the reservoir were studied by using the concept of streamline.

In the oil reservoirs, increasing injection flow rate does not necessarily enhance oil displacement and recovery. therefore, suitable injection rates according to injection and production wells position have to be optimised. Also, production wells flow rate can affect sweep efficiency optimisation extremely and increase the efficiency of injection wells. In this study, according to the position of production and injection wells and water production rates resulting from injection wells, four scenarios with different injection and production rates were investigated. This optimization has led to a reduced water production and water injection. Also, it increased the production efficiency and reservoir life.

Keywords: Production Efficiency, Oil Displacement Efficiency, Streamline, Production well, Injection well, Optimal positioning 
2 Streamline simulation is a powerful tool to the more accurate investigation. In this method,

3 streamlines are drawn by using fluid flow velocity then by the concept of time of flight (TOF),

4 saturation equation is solved. With a time of flight coordinate, three-dimensional saturation

5 equation is converted to one-dimensional equations and the effect of the non-homogeneous

6 reservoir in term of fluid flow time from one point to another is expressed (Datta-Gupta et

7 al.,2007). Equations rather than on cell to cell are solved along the streamlines. Streamline

8 simulation, in large models and more than 80000 cells, uses lower memory and is faster 20 times

9 than Eclipse. Production from hydrocarbon reservoirs requires precise determination of reservoir

10 fluid properties along with their positive impact on real reservoir performance evaluation and

11 fluid in place volume calculation (Nasriani et al., 2015a; Nasriani et al., 2015b). The streamline

12 approach minimises the numerical dispersion and grid orientation effects compared to

13 conventional finite difference method. (Rodriguez et al.,2008; Samier et al., 2001). Streamlines

14 offer the unique ability to define dynamic well allocation factors between injection and

15 producing wells. By this factor relationship between injection and production well pairs for

16 determining parameters are known and can be investigated in details. (Thiele et al., 2003).

17 Pressure maintenance and different fluid phase injection are the common practices used in the oil 18 and gas fields to alleviate the negative impact of reservoir depletion on hydrocarbon recovery 19 (Zareenejad et al., 2015; Nassiri et al., 2015; Nasriani et al., 2014). Water flooding is the most 20 common way which is used to improve oil production in the world. The success of water flood 21 depends on its ability to sweep remaining oil efficiently. The incorrect or insufficient design may 22 lead to increases in cost associated with water cycling and poor sweep (Izgec et al., 2010). 23 Reservoir heterogeneity, permeability contrast, in particular, can adversely impact the 
1 performance of water flooding. It is well-known that the presence of high permeability streaks

2 can severely reduce volumetric sweep efficiency leading to an early water arrival at the

3 producers and bypassed oil. Also, there is an increased cost associated with water recycling and

4 handling. One approach to counteract the impact of heterogeneity and to improve oil

5 displacement is the management of production and injection rate. We can manage the

6 propagation of flood front, delay water breakthrough at the producers and also increase the

7 production efficiency. (Alhuthali et al ., 2006; Grinestaff et al., 1999).

8 In this project more accurate investigation on wells that have production capability but quickly

9 closed was done. According to the position of production and injection wells and water

10 producing, changes in rates were done (Singhal., 2009 ; Sayyafzadeh et al ., 2010 ). Wells

11 shutting was postponed and increasing of oil displacement and production efficiency was

12 concluded.

\section{About the model}

\section{1) Base Case}

15 Table 1 explains average rock and fluid properties. This model has 12 production and 3 injection

16 wells and the irregular pattern is used for injection. Initially, all production wells were produced

17 with 2000 STB/D and injection wells were injected with 6000 STB/D. Schematic of streamline 18 and wells location is shown in Figure 1.

\section{Methodology}

20 In this model, based on prediction, $\mathrm{P} 2$ and $\mathrm{P} 4$ were shut at an early time after production. By

21 running two scenarios that changing the injection and production rates were applied and delaying

22 the wells shutting time, the efficiency of two wells and field efficiency were increased. Three 
1 parameters to compare the scenarios efficiency are: Oil Displacement in reservoir ${ }^{1}$, Oil saturation

2 displaced, Production Efficiency

3 The amount of oil displacement is determined the proportion of initial oil in reservoir and

4 saturation displaced is the determined proportion of pore volume that both of water and oil fill

5 there.

6 These parameters are determined by equations $1,2,3$

$7 \quad$ Oil Displacement $=\frac{O O I P_{i}-O I P_{i}}{O O I P_{i}}$

$\mathrm{Eq}-1$

$8 O I P_{\tilde{i}}$ : Oil remaining between injection - production well pair i

$9 O O I P_{i}$ : Initial oil in place between injection - production well pair i

10 Oil Saturation displaced $=\frac{S o_{i-}(S o)_{i}}{S o_{i}}$

$\mathrm{Eq}-2$

$11 \mathrm{So}_{\mathrm{i}}$ : Initial oil saturation between injection - production well pair i

$12\left(S_{0}\right)_{i}$ : Oil saturation remaining between injection - production well pair i

14 Production Efficiency $=\frac{Q_{o_{i}}}{Q_{t}}$ $\mathrm{Eq}-3$

$15 Q o_{i}$ : Oil production rates in well $\mathrm{i}$ affected by the respective injection wells

$16 Q_{t}$ : Total liquid production in well i affected by the respective injection wells

1 - volumetric sweep efficiency 


\section{2) First Scenario (reducing water injection rate of I1)}

3 Since a high portion of water production in $\mathrm{P} 4$ is affected by $\mathrm{I} 1$, in order to compensate this

4 problem, the flow rate of I1 was reduced to 5000 STB/D. this postpones P4 shutting time two

5 months. Since P3 is influenced by I1 and I2, this task equilibrated the effect of I2 on P2 and P3,

6 This means that P3 was most affected by $\mathrm{I} 2$ and shutting of P2 was postponed 4 months.

\section{3) Second Scenario (reducing water injection rate of I2)}

8 Most of the water production in P2 was allocated by I2 (injection well 2). So, at second scenario

9 flow rate of 12 was reduced to 5000 STB/D. P3 was affected by I1 and I2. Since most of the oil

10 production in $\mathrm{P} 2$ was influenced by $\mathrm{I} 2$ and whereas $\mathrm{I} 2$ flow rate was reduced so it caused P3 to

11 be more influenced by $\mathrm{I} 1$ and it made P4 flow rate that to be less affected by I1, is reduced. So in

12 order to resolve this problem flow rate of I1 is increased to $6500 \mathrm{STB} / \mathrm{D}$.

13 These changing in flow rate caused shutting of P2 and P4 to be delayed 7 and 2 months

14 respectively. in this scenario, Field cumulative water production was reduced 1800000 STB

15 .Also, the amount of cumulative water injections was reduced 2024000 STB.

\section{4) Third Scenario (increasing water injection rate of I1 and I3)}

17 In the second scenario, by reducing the injection rate of $\mathrm{I} 2$, P2 was more affected by I3 than 18 before and the effect of I3 on P1 was reduced. So in the third scenario, flow rates of I1 and I3 19 were increased to $6500 \mathrm{STB} / \mathrm{D}$ and in order to reduce water production in $\mathrm{P} 2$, the $\mathrm{I} 2$ flow rate 20 was decreased to $4500 \mathrm{STB} / \mathrm{D}$. But this scenario compared to the second scenario wasn't 21 efficient. This suggests that just changing in injection rates is not enough for increasing 
1 production efficiency. So production flow rate must change too. The fourth scenario performed

2 this process.

\section{5) Fourth Scenario (increasing $I 1$ and $I 3$ injection rate and decreasing $I 2$ injection rate)}

$4 \quad \mathrm{P} 1$ and P2 are affected by I3 in the fourth scenario, in order to increase P2 efficiency, I2 flow 5 rate was reduced to $4500 \mathrm{STB} / \mathrm{D}$ and I1, I3 were increased to $6500 \mathrm{STB} / \mathrm{D}$. Since P2 is more

6 affected by $\mathrm{I} 3$ than before and P1 is influenced by I3, it causes P2 efficiency to decrease. So I3

7 flow rate was increased to 6500 STB/D. Due to P11 and P12 vicinity to the aquifer and their low

8 efficiency, flow rates of these wells were decreased to 1000 and 1500 STB/D. also, the P3 flow

9 rate was reduced to 1500 STB/D respectively. it was because of reducing P4 efficiency by P3 in

10 order to compensate for this production reduction, flow rates of P1 ,P2, P6 and P7 were

11 increased to 2500 STB/D. flow rate increase was done for several reasons:

12 1. Higher volume of oil in place in related area to these wells

13 2. Higher production capability than the other wells

143 . Increasing the flow rates in injection wells which affect oil production rate, cause better

15 volumetric sweep efficiency in the related area

16 In the fourth scenario, shutting of P2 and P4 were delayed 11 and 9 months respectively. Water

17 production was decreased more than before. Figure 2 shows differences between water 18 production in the base case and four Scenarios.

19 Figure 3 and 4 show oil displacement and oil saturation displaced for P2 and P4. The fourth 20 scenario was more efficient than the other scenarios and Wells have been able to have more 21 producing time. 
1 Figure 5 shows production efficiency for P2 and P4 at different scenario at the base case P2 and

2 P4 were shut after 3012 days after production, so if production efficiency of all scenarios is

3 compared at the same period of time (3012 days), the fourth scenario is more effective than base

4 case and other scenarios.

5 Shut-in times of all scenarios are shown in table 2.

6

\section{Conclusion}

8 With increasing injection flow rate, oil displacement and recovery don't become better than

9 before necessarily. So, suitable injection rates according to injection and production wells

10 position have to be determined. Also, production wells flow rate can affect sweep efficiency

11 optimisation extremely and increase the efficiency of injection wells. In this study, according to

12 the position of production and injection wells and water production rates resulting from injection

13 wells, four scenarios with changes in the injection and production rates were investigated. This

14 led to being reduced water production and water injection. Also, increasing production efficiency

15 and reservoir life resulted.

\section{Suggestions}

- Before field development, distances between production and injection wells should be optimised. It is because of avoiding the cost increase related to drilling repetition and using more water to inject. rate cannot sweep this area. Otherwise, this case may lead to higher costs. 
- Wells completion in the layers close to the aquifer can cause wells to be shut faster.

- Only changing in water rates of injection wells is not enough for increasing production efficiency. Changing in production flow rate must be applied too.

\section{References}

Alhuthali,A.H., Oyerinde,D., and Datta-Gupta,A. Optimal Waterflood Management Optimal Waterflood Management Using Rate Control. SPE 102478, Annual Technical Conference and Exhibition, San Antonio, Texas, USA, 24-27 September 2006

Rodriguez,A., Davood ,N.J., Soremi,A., and Taiban, A. Practical Aspects of Streamline Application to Water Injection Management of a Giant Carbonate Reservoir. SPE 112899. North Africa Technical Conference \& Exhibition, Marrakech, Morocco, 12-14 March 2008

Singhal, A. K., Improving Water Flood Performance by Varying Injection-Production Rates. PETSOC-2009-126. , Canadian International Petroleum Conference, Calgary, Alberta, 16-18 June 2009

Grinestaff, G.H .Water Flood Pattern Allocation: Quantifying the Injector to Producer Relationship with Streamline Simulation. SPE 54616. Western Regional Meeting, Anchorage, Alaska, 26-27 May 1999

Datta-Gupta, A. ,Texas A \& M University, King, M.J., BP America, Streamline Simulation: Theory and Practice., Society of Petroleum Engineering, 222 Palisades Creek Drive, Richardson, TX 75080-2040, USA , 2007 
Thiele, M. R., and Batycky, R. P., Water Injection Optimization Using a Streamline- Based Workflow. SPE 84080, Annual Technical Conference and Exhibition, Denver, Colorado, 5-8 October 2003

Nasiri Ghiri, M., Nasriani, H.R., Sinaei, M., Najibi, S.H., Nasriani, E., Parchami, H., Gas Injection for Enhancement of Condensate Recovery in a Gas Condensate Reservoir. (2015) Energy Sources, Part A: Recovery, Utilization and Environmental Effects, 37 (8), pp. 799806. DOI: $10.1080 / 15567036.2011 .596901$

Nasriani, H.R., Asadi, E., Nasiri, M., Khajenoori, L., Masihi, M., Challenges of fluid phase behavior modeling in Iranian retrograde gas condensate reservoirs. (2015a) Energy Sources, Part A: Recovery, Utilization and Environmental Effects, 37 (6), pp. 663-669. DOI: $10.1080 / 15567036.2011 .594865$

Nasriani, H.R., Borazjani, A.A., Iraji, B., MoradiDowlatAbad, M., Investigation into the effect of capillary number on productivity of a lean gas condensate reservoir. (2015b) Journal of Petroleum Science and Engineering, 135, pp. 384-390. DOI: 10.1016/j.petrol.2015.09.030

Nasriani, H.R., Borazjani, A.A., Sinaei, M., Hashemi, A., The effect of gas injection on the enhancement of condensate recovery in gas condensate reservoirs: A comparison between a synthetic model and PVT cell results. (2014) Petroleum Science and Technology, 32 (5), pp. 593-601. DOI: 10.1080/10916466.2011.596890

Sayyafzadeh,M., Pourafshary, P., and Rashidi,F. Increasing Ultimate Oil Recovery by Infill Drilling and Converting Weak Production Wells to Injection Wells Using Streamline Simulation . SPE 132125-MS, International Oil and Gas Conference and Exhibition in China, Beijing, China, 8-10 June 2010 
1 Izgec, O., Sayarpour, M., and Shook, G.M., Optimizing Volumetric Sweep Efficiency in Water 2 flood by Integrating Streamlines, Design of Experiments, and Hydrocarbon F- $\varphi$ Curves.SPE 132609. Western Regional Meeting, Anaheim, California, USA , 27-29 May 2010

5 Samier, P., Quettier, L., and Thiele, M.R , Applications of Streamline Simulations to Reservoir Studies. SPE 66362. Reservoir Simulation Symposium, Houston, Texas, 11-14 February 2001

8 Zareenejad, M.H., Kalantari Asl, A., Nasriani, H.R., Zargar, Gh., Analysis and comparison of 9 decline models: A field case study of a naturally fractured gas condensate reservoir. (2015) 400. DOI: $10.1080 / 15567036.2011 .576409$ 
Table.1-Average Rock and Fluid properties

\begin{tabular}{|l|c|}
\hline \multicolumn{1}{|c|}{ Property } & Average Amount \\
\hline Permeability in X direction & 27.5 md \\
\hline Permeability in Y direction & 27.5 md \\
\hline Permeability in Z direction & 50.4 md \\
\hline Porosity & $20 \%$ \\
\hline Initial Oil Saturation & $75 \%$ \\
\hline Initial Gas Saturation & $0 \%$ \\
\hline Initial Water Saturation & $25 \%$ \\
\hline Oil Density(Standard Condition) & 52.1 Ib/cu.ft \\
\hline Gas Density(Standard Condition) & 0.055 Ib/cu.ft \\
\hline Water Density(Standard Condition) & 62.3 Ib/cu.ft \\
\hline Initial Pressure & 3170 Psia \\
\hline
\end{tabular}


Table.2- Wells shut-in times

\begin{tabular}{|c|c|c|c|c|c|}
\hline & Initial & $\mathbf{1}^{\text {st }}$ Scenario & $\mathbf{2}^{\text {nd }}$ Scenario & $\mathbf{3}^{\text {rd }}$ Scenario & $\mathbf{4}^{\text {th }}$ Scenario \\
\hline $\mathbf{P 2}$ & 1-May-17 & $1-$ Sep-17 & 1-Dec-17 & 1-Dec-17 & $1-$ Apr-18 \\
\hline $\mathbf{P 4}$ & 1-Aug-14 & $1-$-Oct-14 & $1-$ Oct-14 & 1-Aug-14 & 1 -May-15 \\
\hline
\end{tabular}




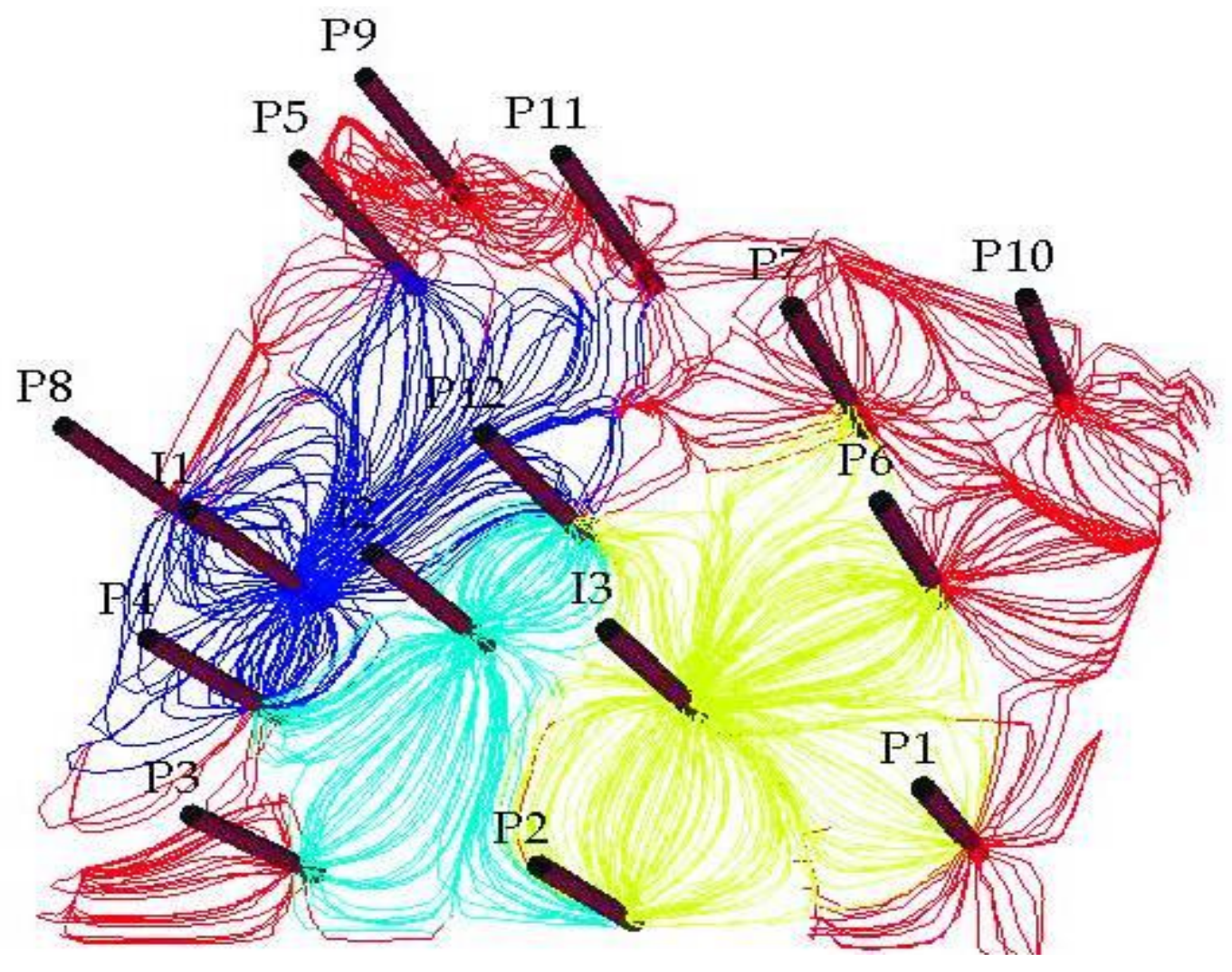

Figure.1- Schematic of stream lines and wells location 


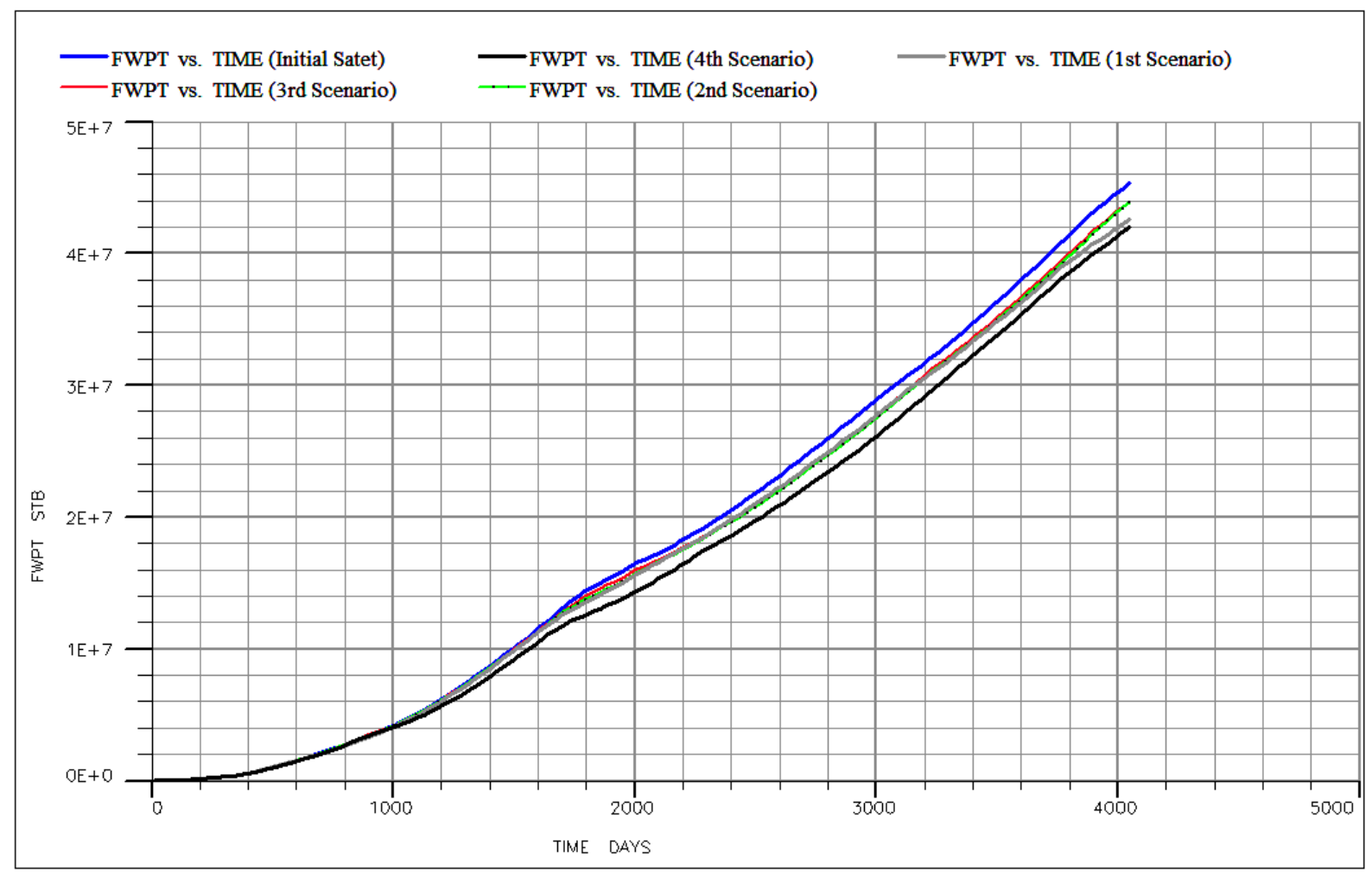

Figure.2-Comparing water production between base case and four scenarios 

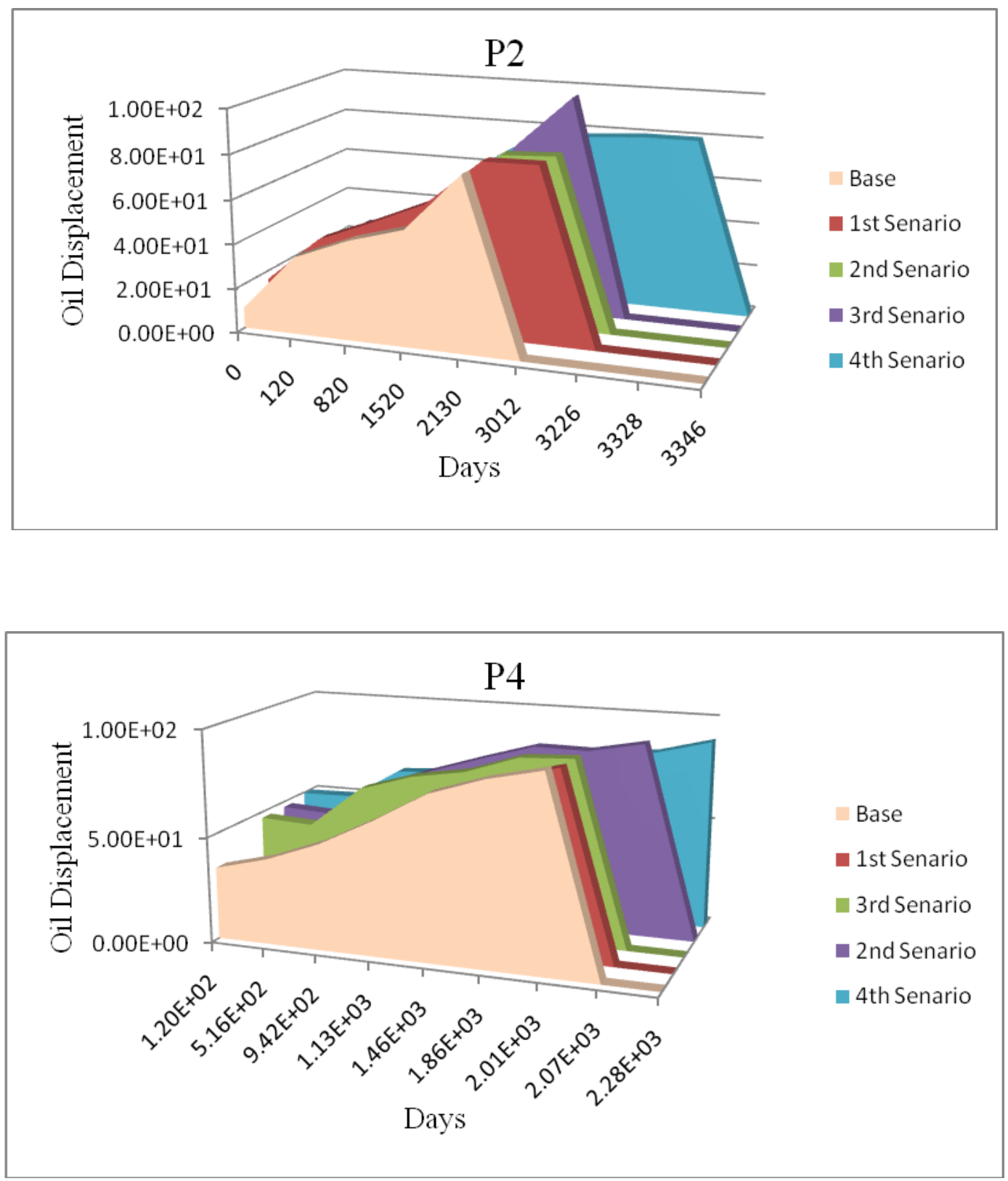

Figure.3-Oil Displacement for area related to P2 and P4 

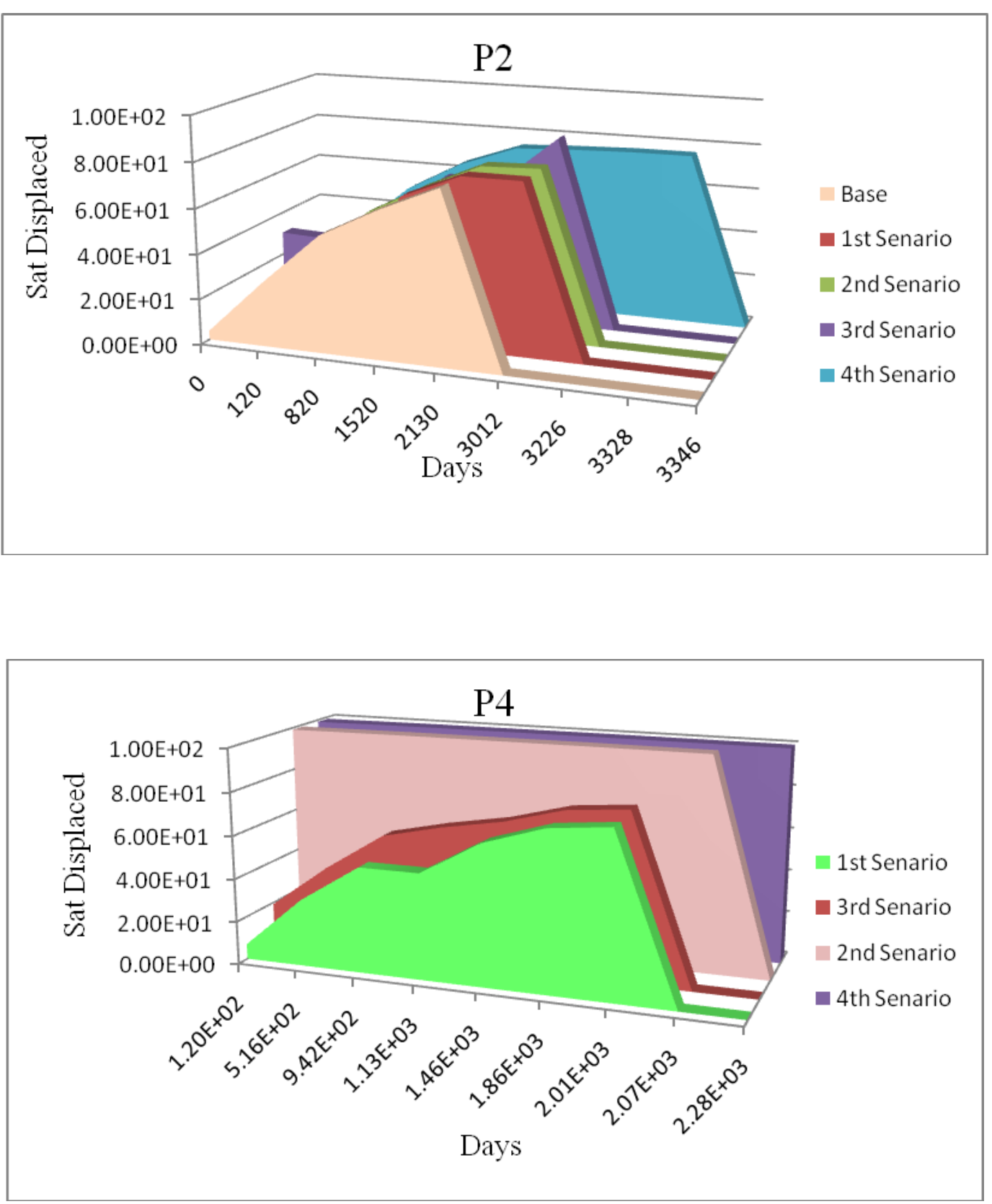

Figure.4-Saturation Displaced for area related to P2 and P4 


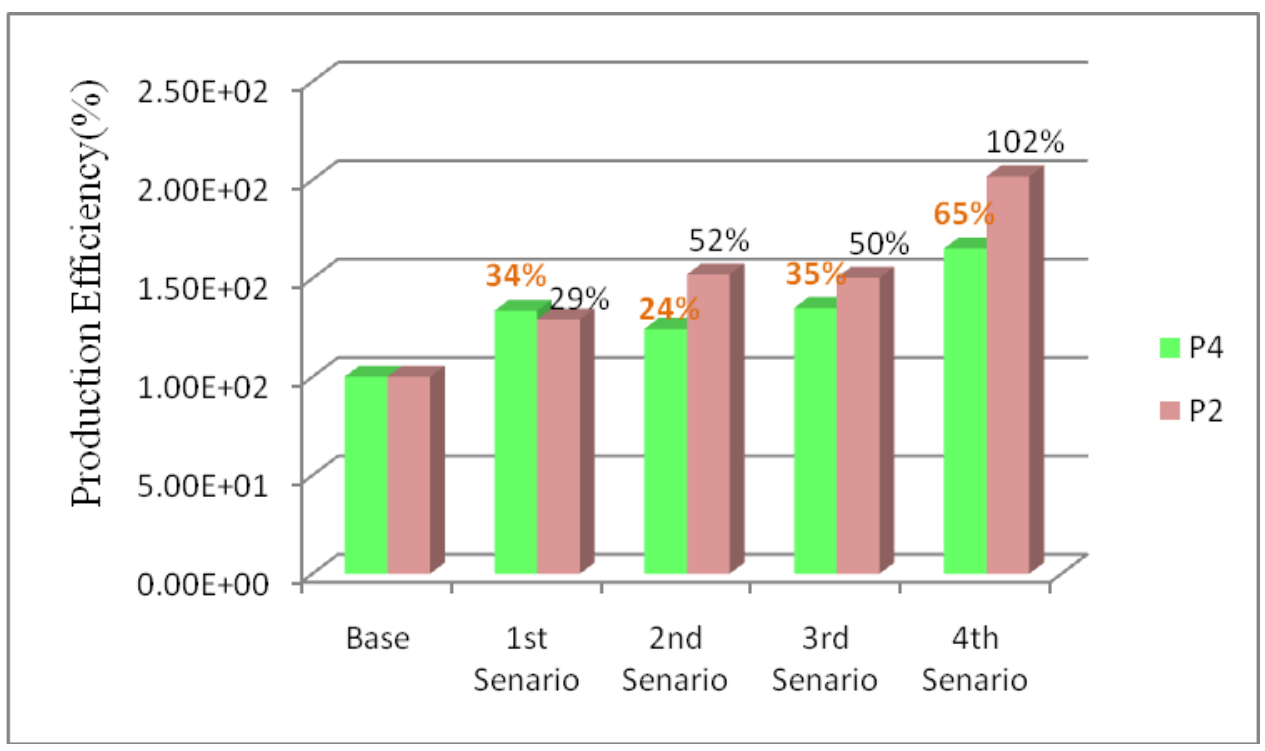

Figure.5- Production Efficiency for P2 and P4 